\title{
Purification and properties of sulfite oxidase from different sources: a mini review
}

\begin{abstract}
Sulfite oxidase (EC 1.8.3.1) known to catalyse the aerobic oxidation of sulfite into sulfate, is found in the mitochondria of all eukaryotes. It was first isolated from bovine liver and subsequently purified from both animal and plant sources such as rat, dog, beef, humans, chicken and goat liver (animals) and plant Spinacia oleracea, Malva sylvestris, Nicotiana tabacum and Arabidopsis thaliana (plants). Various physiological properties of purified $\mathrm{SO}_{\mathrm{x}}$ have been studied e.g. molecular weight, optimum $\mathrm{pH}$, temperature, time, $\mathrm{K}_{\mathrm{m}}$ \& for sulfite metal ions activation and inhibition.
\end{abstract}

Volume 6 Issue I - 2019

Rachna Rawal, Chandra Shekhar Pundir
Department of Biochemistry, M D University, India

Correspondence: Rachna Rawal, Department of Biochemistry, M.D.University, Rohtak-12400 I, Haryana, India, Tel +919896656383, Email rachu_biochem@yahoo.com

Received: September 18, 2018 | Published: January 18, 2019

\section{Introduction}

Sulfite oxidase $\left(\mathrm{SO}_{\mathrm{x}}\right)$ (EC 1.8.3.1) is found in the mitochondria of all eukaryotes. It oxidizes sulfite to sulfate and via cytochrome c. It transfers the electrons produced to the electron transport chain (ETC), allowing generation of ATP by oxidative phosphorylation. This is the last step in the metabolism of sulfur-containing compounds and the sulfate is excreted. $\mathrm{SO}_{\mathrm{x}}$ is a metallo-enzyme containing a molybdopterin cofactor and a heme group. It is one of the cytochrome $b_{5}$ and belongs to the enzyme super-family of molybdenum oxotransferases that also includes dimethylsulfoxide (DMSO) reductase, xanthine oxidase and nitrite reductase. In mammals, the expression level of $\mathrm{SO}_{\mathrm{x}}$ is high in the liver, kidney and heart but very low in spleen, brain, skeletal muscle and blood ${ }^{1-3}$ of functional $\mathrm{SO}_{\mathrm{x}}$ causes sulfite deficiency. This causes neurological disorders, mental retardation, physical deformities, dislocated lenses, degradation of brain and early death thus sulfite level in body must normally be strictly maintained. SOx was first isolated from bovine liver and subsequently also purified from animal sources such as rat, dog, beef, humans, chicken and goat liver and plant sources such as Spinacia oleracea, Malva sylvestris, Nicotiana tabacum and Arabidopsis thaliana (Table 1). ${ }^{4}$ The present review deals with the distribution, purification, and characterization of $\mathrm{SO}_{\mathrm{x}}$ from various sources.

Table I Sources of sulfite oxidase

\begin{tabular}{llll}
\hline Source & Type & Tissue/localization & References \\
\hline Plant & & & \\
$\begin{array}{l}\text { Spinach (Spinacia oleracea) } \\
\text { Arabidopsis thaliana }\end{array}$ & Plant & leaves & Jolivet et al. ${ }^{9}$ \\
Malva sylvestris & Plant & leaves & Eilers et al. ${ }^{4}$ \\
Animal & Plant & leaves & Ganai et al. ${ }^{8}$ \\
Rat, beef, dog & & & \\
Human & Animal & liver & Macleod et al. ${ }^{14}$ \\
Bovine & Animal & liver & Johnson \& Rajgopalan" \\
Chicken & Animal & liver & Cohen \& Fridovich ${ }^{3}$ \\
Merluccius products (pacific hake) & Animal & liver & Kessler and Rajgopalan ${ }^{12}$ \\
Goat (Capra hircus) & Animal & liver & Onoue ${ }^{15}$ \\
\hline
\end{tabular}

Purification and properties of sulfite oxidase from different sources

$\mathrm{SO}_{\mathrm{x}}$ has been purified from different sources with varying molecular weight, opitimum $\mathrm{pH}$, incubation temperature, $\mathrm{K}_{\mathrm{m},}$ metal ion requirement and inhibition.

\section{Purification}

Goat $\mathrm{SO}_{\mathrm{x}}$ was purified from liver by ammonium sulfate precipitation $(50 \%)$, ion exchange chromatography (DEAE-cellulose,
DE-52) and gel filtration by 92.56 fold purification with $7.30 \%$ yield, ${ }^{5}$ Sulfitobacter pontiacus $\mathrm{SO}_{\mathrm{x}}$ was purified by cation- exchange absorber and ultrafiltration with 20 fold purification and a specific activity of $188 \mathrm{U} / \mathrm{mg},{ }^{6}$ Thermus thermophilus cell material $\mathrm{SO}_{\mathrm{x}}$ was purified by ammonium sulfate precipitation ( $60 \%$ saturation), DEAE 52 column chromatography, superdex X26 gel filtration and Mono Q with 297 fold purification, 14\% yield and specific activity of 56.67 $\mathrm{U} / \mathrm{mg},{ }^{7}$ Arabidopsis thaliana $\mathrm{SO}_{\mathrm{x}}$ was purified by Q30, superdex 200 FPLC with 12.84 fold purification and $10.7 \%$ yield, ${ }^{4}$ Nicotiana $\mathrm{SO}_{\mathrm{x}}$ was purified from leaves by ion exchange chromatography followed 
by FPLC size exclusion with 100 fold purification, ${ }^{4}$ Malva sylvestris $\mathrm{SO}_{\mathrm{X}}$ was purified from leaves by heat treatment, ion exchange chromatography and sephadex gel chromatography with 8.3 fold purification and $28 \%$ yield, ${ }^{8}$ Spinach $\mathrm{SO}_{\mathrm{x}}$ was purified from thylakoid by ammonium sulfate acetone precipitation $(50 \%)$, dialysis and DEAE- cellulose column chromatography, ${ }^{9}$ Thiobacillus novellus $\mathrm{SO}_{\mathrm{x}}$ was purified by DEAE-cellulose, hydroxyapatite, affi-Gel blue with 206 fold purification and 3.4\% yield, ${ }^{10}$ human and rat $\mathrm{SO}_{\mathrm{x}}$ was purified from liver by heating, ammonium sulfate precipitate, acetone, DE-52 ion exchange chromatography with 6459 and 1113 folds purification and $9 \%$ and $6 \%$ yields respectively, ${ }^{11} \mathrm{SO}_{\mathrm{x}}$ was purified from liver by heating $\left(56^{\circ} \mathrm{C}\right)$, ammonium sulfate precipitation $(50 \%)$, DEAE-cellulose and gel fractionation on Sephadex G-200 with 530 fold purification and $10 \%$ yield, ${ }^{12}$ Hepatic $\mathrm{SO}_{\mathrm{x}}$ was purified from chicken liver by heating $\left(60^{\circ} \mathrm{C}\right)$, ammonium sulfate precipitation (40\%) and DEAE cellulose ion exchange with 802 fold purification and $12 \%$ yield, ${ }^{13}$ Thiobacillus novellus $\mathrm{SO}_{\mathrm{x}}$ was purified from 6 day old cells by sonication, ammonium sulfate precipitate ( $40 \%)$, heating and ammonium sulfate precipitation (40-70\%), beef $\mathrm{SO}_{x}$ was purified from liver by ammonium sulfate precipitate $(0-50 \%)$, heat $\left(55^{\circ} \mathrm{C}\right)$, first DEAE cellulose column, ammonium sulfate precipitation $(0-50 \%)$, second DEAE cellulose column chromatography, ammonium sulfate precipitation (0-50\%) and third DEAE cellulose column, ammonium sulfate precipitate $(0-50 \%)$ with 233 fold purification, $7.8 \%$ yield and with a specific activity of $280 \mathrm{U} / \mathrm{mg}^{14}$ and dog sulfite oxidae was purified from liver by protamine sulfate supernatant, ammonium sulfate precipitation $(0-50 \%)$, first DEAE cellulose column and second DEAE cellulose column with 385 fold purification, $16 \%$ yield and specific activity of $27.10 \mathrm{U} / \mathrm{mg} .{ }^{14}$

\section{Molecular weights}

The molecular weights of $\mathrm{SO}_{\mathrm{x}}$ purified from different sources were in the range, 27 to $113 \mathrm{kDa}$. The molecular weights of purified enzyme from different sources has been summarized in Table 2 .

Table 2 Determination of molecular wt. of sulfite oxidase from different sources

\begin{tabular}{|c|c|c|c|}
\hline Source & Method of determination & $\begin{array}{l}\text { Molecular wt. } \\
\text { (Dalton) }\end{array}$ & References \\
\hline Capra hircus & Gel filtration & 113000 & Ahmad et al..$^{5}$ \\
\hline Homosapiens & Sedimentation equilibrium analysis & 101000 & Wilson et al. ${ }^{17}$ \\
\hline Thermus thermophilus & Gel filtration & 38000 & Di Salle et al. ${ }^{7}$ \\
\hline Deinococcus radiodurans & Calculated from sequence of cDNA & 38940 & D'Errico et al.' \\
\hline Arabidopsis thaliana & Gel filtration & 40000 & Eilers et al. ${ }^{4}$ \\
\hline Malva sylvestris & Gel filtration & 27000 & Ganai et al. ${ }^{8}$ \\
\hline Merluccius products & Gel filtration & 120000 & Onoue ${ }^{15}$ \\
\hline Rattus norvegicus & Sedimentation equilibrium centrifugation & 120000 & Southerland et al. ${ }^{18}$ \\
\hline Bos Taurus & Gel filtration & 120000 & Cohen \& Fridovich ${ }^{3}$ \\
\hline
\end{tabular}

\section{Optimum pH}

The optimum $\mathrm{pH}$ of $\mathrm{SO}_{\mathrm{x}}$ purified from different sources was in neutral to alkaline range i.e. $\mathrm{pH} 7-11$. The functional groups in side chain of amino acid residues at the catalytic site as well as in the peptide backbone of enzyme are vital for catalytic action of enzyme. In alkaline $\mathrm{pH}$ range, the $-\mathrm{NH}_{2}$ group of side chain of Lys, His, Arg controls the activity of $\mathrm{SO}_{x}$. The optimum $\mathrm{pH}$ of $\mathrm{SO}_{\mathrm{x}}$ from different sources is summarized in Table 3 .

Table 3 Optimum pH of sulfite oxidase from different sources

\begin{tabular}{|c|c|c|}
\hline Source & $\begin{array}{l}\text { Optimum } \\
\text { pH }\end{array}$ & References \\
\hline Homosapiens & 7 & Dronov et al. ${ }^{19}$ \\
\hline Acidithiobacillus thiooxidans & 7.5 & Negishi et al. ${ }^{20}$ \\
\hline Rattus norvegicus & 7.5 & Shibuya \& Horie ${ }^{25}$ \\
\hline Spinacia oleracea & 7.6 & Jolivet et al. ${ }^{9}$ \\
\hline Malva sylvestris & 7.8 & Ganai et al. ${ }^{8}$ \\
\hline Arabidopsis thaliana & 8.5 & Hemann \\
\hline Bos Taurus, Canis lupis familiaris & 8.5 & Macleod et al. ${ }^{14}$ \\
\hline Capra hircus & 8.5 & Ahmad et al. ${ }^{5}$ \\
\hline Bos Taurus & 8.6 & Cohen \& Fridovich ${ }^{3}$ \\
\hline Merluccius products & 8.7 & Onoue $^{15}$ \\
\hline Thermus thermophilus & $\mathrm{II}$ & Di Salle et al. ${ }^{7}$ \\
\hline
\end{tabular}

\section{Optimum temperature}

Every enzyme works at its maximum rate at a specific temperature called as optimum temperature for that enzyme. $\mathrm{SO}_{\mathrm{x}}$ isolated and purified from different sources had a wide range of optimum temperature $20-60^{\circ} \mathrm{C}$. The optimum temperature of an enzyme can be explained on the basis of kinetic theory, which states that increased temperature increases the speed of molecular movement and thus the chances of molecular collisions which is directly proportional to incubation temp. The optimum temp. of $\mathrm{SO}_{\mathrm{x}}$ from different sources is summarized in Table 4.

Table 4 Optimum temperature of sulfite oxidase from different sources

\begin{tabular}{|c|c|c|}
\hline Source & $\begin{array}{l}\text { Optimum } \\
\text { temperature }\left({ }^{\circ} \mathrm{C}\right)\end{array}$ & References \\
\hline Homosapiens & 25 & Wilson et al. ${ }^{17}$ \\
\hline Capra hircus & 25 & Ahmad et al..$^{5}$ \\
\hline Malva sylvestris & 30 & Ganai et al. ${ }^{8}$ \\
\hline Acidithiobacillus thiooxidans & 30 & Negishi et al. ${ }^{20}$ \\
\hline Spinacia oleracea & 55 & Jolivet et al. ${ }^{9}$ \\
\hline Deinococcus radiodurans & 55 & D'Errico et al. ${ }^{\prime}$ \\
\hline Thermus thermophilus & 60 & Di Salle et al. ${ }^{7}$ \\
\hline
\end{tabular}




\section{Michaelis kinetic constant $\left(\mathrm{K}_{\mathrm{m}}\right)$}

The measurement of Michaelis kinetic constant $\mathrm{K}_{\mathrm{m}}$ for sulfite from various sources has been calculated from Lineweaver-Burk (LB) plot. $\mathrm{K}_{\mathrm{m}}$ for $\mathrm{SO}_{\mathrm{x}}$ was found in a wide range, $0.00092 \mathrm{mM}$ to $5.33 \mathrm{mM} . \mathrm{K}_{\mathrm{m}}$ value of $\mathrm{SO}_{\mathrm{x}}$ from different sources is summarized in Table 5.

Table $5 \mathrm{~K}_{\mathrm{m}}$ of sulfite oxidase from different sources

\begin{tabular}{lll}
\hline Source & $\mathbf{K}_{\mathbf{m}}$ for sulfite & Reference \\
\hline Gallus gallus & 0.00092 & Ritzman \& Bosshard ${ }^{23}$ \\
Homosapiens & 0.00129 & Wilson et al. ${ }^{17}$ \\
Arabidopsis thaliana & 0.034 & Eilers et al. $^{4}$ \\
Nicotiana tabacum & $0.05 \mathrm{I}$ & Eilers et al. $^{4}$ \\
Deinococcus radiodurans & 0.0945 & D'Errico et al. $^{1}$ \\
Bos Taurus & 0.39 & Bray $^{24}$ \\
Mus musculus & 0.39 & Shibuya \& Horie ${ }^{25}$ \\
Capra hircus & 0.698 & Ahmad et al. ${ }^{5}$ \\
Rattus norvegicus & 0.17 & Ito et al. ${ }^{26}$ \\
Vertebrata & 0.002 & Kuwahara et al..$^{27}$ \\
Malva sylvestris & 5.33 & Ganai et al. ${ }^{8}$ \\
\hline
\end{tabular}

\section{Inhibition studies}

$\mathrm{SO}_{\mathrm{x}}$ from various sources was inhibited by a number of compounds including metal ions and substrate analogues such as arsenite, EDTA, imidazole, Ethyl-3 (3-dimethylaminopropyl) carbodiimide hydrochloride, diethylpyro-carbonate, N-ethyl-5-phenylisoxazolium3'-sulfonate, 2,6-dichloroindophenol, cyanide, cyt c, ferricyanide, sodium tungstate, $\mathrm{NaCl}$, potassium nitrate, potassium phosphate and Tris- $\mathrm{HCl}$ buffer. A list of various inhibitors is given in Table 6.

Table 6 Effect of various inhibitors and substrate analogs on sulfite oxidase from different sources

\begin{tabular}{|c|c|c|c|}
\hline Source & Inhibitor & Type of inhibition & Reference \\
\hline Thermus thermophilus & Arsenite, $\mathrm{Ca}^{2}+$ & $7.4 \mathrm{mM}, 50 \%$ inhibition & Di Salle et al. ${ }^{7}$ \\
\hline $\begin{array}{l}\text { Deinococcus } \\
\text { radiodurans }\end{array}$ & EDTA, imidazole & $0.1 \mathrm{mM}$, complete inhibition & D'Errico et al.' \\
\hline $\begin{array}{l}\text { Acidithiobacillus } \\
\text { thiooxidans }\end{array}$ & $\mathrm{Ni}^{2}+$, sodium tungstate & $\begin{array}{l}\text { Stronger inhibition at } \mathrm{pH} 7.0 \text { than } \\
\text { at } \mathrm{pH} 3.0\end{array}$ & Negishi et al. ${ }^{20}$ \\
\hline Arabidopsis thaliana & $\mathrm{NaCl}$, potassium nitrate, potassium phosphate, Tris- $\mathrm{HCl}$ buffer & $50 \%$ inhibition at $30 \mathrm{mM}, \mathrm{pH} 8.5$ & Eilers et al. ${ }^{4}$ \\
\hline Homosapiens & Arsenate, phosphate & $20 \%$ inhibition at $100 \mathrm{mM}$ & George et al. ${ }^{28}$ \\
\hline Gallus gallus & $\begin{array}{l}\text { Ethyl-3 (3 dimethylaminopropyl) carbodiimide hydrochloride, } \\
\text { Diethylpyro-carbonate, N-ethyl-5-phenylisoxazolium-3'-sulfonate }\end{array}$ & $\begin{array}{l}\text { EDC, modifies ten His per enzyme } \\
\text { molecule, Woodward's reagent } \mathrm{K}\end{array}$ & Ritzman \& Bosshard ${ }^{23}$ \\
\hline Merluccius products & CN-, heavy metal ions, sulfate & $30 \%$ Inhibition more than $10 \mathrm{mM}$ & Onoue $^{15}$ \\
\hline Rattus norvegicus & arsenite, $\mathrm{CN}$ - & - & Bray $^{24}$ \\
\hline Bos Taurus & 2,6-dichloroindophenol, arsenite, CN- Cyt c, Ferricyanide & Inhibition of $\mathrm{O}_{2}$ consumption & Cohen \& Fridovich ${ }^{3}$ \\
\hline
\end{tabular}

\section{D structure of $\mathrm{SO}_{x}$ and mechanism of action}

\section{D structure of $\mathrm{SO}_{x}$}

As a homodimer, $\mathrm{SO}_{\mathrm{x}}$ contains two identical subunits, each with an $\mathrm{N}$-terminal domain and a C-terminal domain. These two domains are connected by ten amino acids forming a loop. The N-terminal domain has a heme cofactor with three adjacent antiparallel beta sheets and five alpha helices. The C-terminal domain hosts a molybdopterin cofactor surrounded by thirteen beta sheets and three alpha helices. The molybdopterin cofactor has a Mo (VI) center, bonded to a sulfur from cysteine, an ene-dithiolate from pyranopterin and two terminal oxygens. It is at this molybdenum center that the catalytic oxidation of sulfite takes place (Figure1).

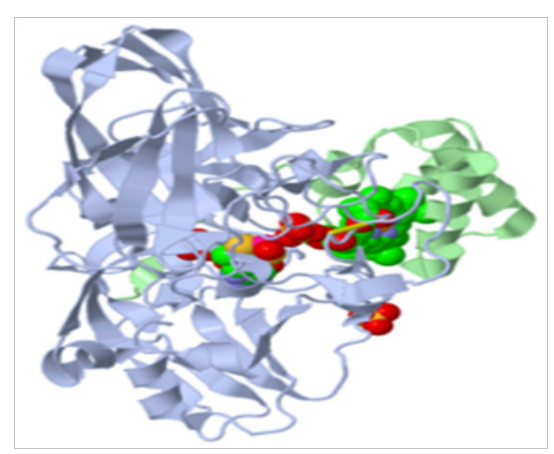

Figure I 3D structure of $\mathrm{SO}_{x}$. 


\section{Mechanism of action of $\mathrm{SO}_{\times}$}

The active site of $\mathrm{SO}_{\mathrm{x}}$ contains the molybdopterin cofactor and supports molybdenum in its highest oxidation state, $+6\left(\mathrm{Mo}^{\mathrm{VI}}\right)$. In the enzyme's oxidized state, molybdenum is coordinated by a cysteine thiolate, the dithiolene group of molybdopterin, and two terminal oxygen atoms. Upon reacting with sulfite, one oxygen atom is transferred to sulfite to produce sulfate and the molybdenum center is reduced by two electrons to $\mathrm{Mo}^{\mathrm{IV}}$. Water then displaces sulfate and the removal of two protons $\left(\mathrm{H}^{+}\right)$and two electrons returns the active site to its original state. A key feature of this oxygen atom transfer in enzyme is that the oxygen atom being transferred arises from water, not from dioxygen $\left(\mathrm{O}_{2}\right)$ (Figure2).

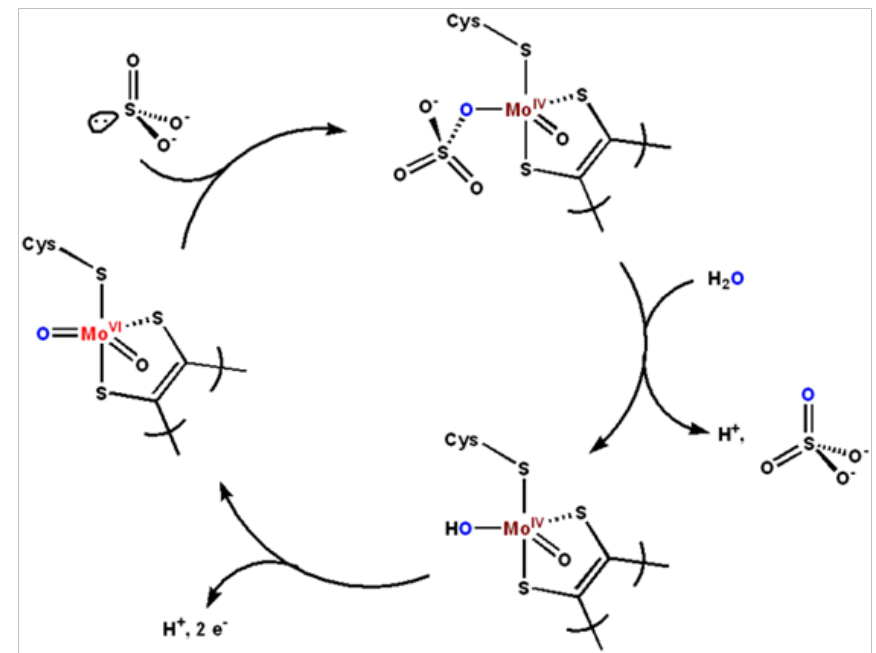

Figure 2 A proposed mechanism of the oxidation of sulfite to sulfate by sulfite oxidase.

\section{Role of sulfite}

\section{In reductive or oxidative sulfur metabolism}

Assimilatory sulfate reduction in plants starts with the uptake of sulfate from soil into the roots and translocation via the xylem to green parts of the plant, where it is stored as the major anionic component of vacuolar sap. ${ }^{15-28}$ Chloroplasts are the limiting organelles where sulfate reduction takes place, only cysteine synthesis enzymes are the ones localized not only in plastids but also in the cytosol and mitochondria. Sulfite is not only a key metabolite in assimilatory sulfate reduction, but also plays a central role in reductive or oxidative sulfur metabolism in both pro- and eukaryotes. In plants, sulfite is also the starting point for the formation of sulfolipids and an intermediate in the oxidation of reduced sulfur compounds to sulfate. Yet, it has to be considered that sulfite reduction and sulfolipid formation are chloroplast-based while sulfite oxidation is localized in peroxisomes.

\section{Antimicrobial effects}

Undissociated sulfonic acid and dissolved sulfur dioxide, respectively, are the most effective forms of S (IV) against microbial organisms, whereas sulfites $\left(\mathrm{SO}_{2}^{-3}\right)$ have only little or no effects. Hydrogen sulfite, the sulfite form most prevalent at normal food $\mathrm{pH}$ values, still has remarkable effects against microbial spoilage, but the effects are less strong than those of the undissociated acid. Furthermore, the intensity of the preservative effects is different for bacteria, yeast and mold fungus and even within these groups, there are also some significant variations. The minimum concentration for an inhibitory effect on bacteria at a $\mathrm{pH}$ value of 6.0 varies between
$500 \mathrm{mg} / \mathrm{L}$ and $2000 \mathrm{mg} / \mathrm{L}$ of sodium sulfite. For an inhibitory effect on yeast and mold, generally lower $\mathrm{pH}$ values or higher concentrations of sodium sulfite are required.

\section{Role of sulfite as preservative}

Sulfite compounds are used as a preservative for food and drinks. Sulfites are a family of chemicals that includes sodium sulfite, sodium bisulfite, sodium metabisulfite, potassium sulfite and potassium metabisulfite. Sulfites are produced naturally during the fermentation of wine. However, the majority of sulfur compounds are produced through chemical synthesis. Sulfites are used to preserve the flavor and appearance of foods such as jam, gravy, shrimp, dried soup mixes, dehydrated potatoes and juices. Fresh or dried fruit and vegetables are sometimes dipped or sprayed with sulfites to not only to kill germs but also to preserve appearance and taste. Sulfites keep vegetables from turning brown. Sodium metabisulfite and potassium metabisulfite are sometimes added to fermenting beer and wine to inhibit microbes and increase shelf life. Sulfites are also added to meat products. Shrimp and lobster spoilage is greatly reduced when these foods are sprayed or dipped in sulfite solutions. Before the U.S. Department of Agriculture banned the practice, meat packagers used to add sulfites to raw meat in order to keep it looking fresh.

\section{Use of sulfite as preservatives in medicine}

Drug manufacturers take advantage of the antimicrobial and antioxidant properties of sulfites to preserve and increase the shelf life of medications. Sulfates are added to asthma inhalants, medicines given by injection, eye drops, oral tablets and liquids. The U.S. Food and Drug Administration (FDA) require that all sulfite containing food and drugs available in the U.S. list the amounts on their labels. However, there is no such rule in India.

\section{Use of sulfite as antioxidants, antimicrobials and bleaching agents}

Sulfites are antioxidants, antimicrobials and bleaching agents. As antioxidants prevent or reduce discoloration of fruits and vegetables, sulfites are commonly used in products such as dried apples, dehydrated potatoes, processed fruit and vegetable juices. It is used in wine-making, because it inhibits bacterial growth but does not interfere with the desired development of yeast. It is used in bleaching food starches and prevents rust and scale formation in boilers. Some sulfites are used in the production of cellophane for food packaging. However, it causes allergic reactions to asthmatics. It causes difficulty in breathing, stomach-ache, hives, bronchospasm and even anaphylactic shock. Sulfite sensitivity occurs most often in asthmatic adults, predominantly women and uncommonly reported in preschool children. The reactions of sulfite sensitive asthmatics to sulfites vary from person to person. It causes anaphylaxis (allergic reaction). Sulfites may also contribute to chronic skin and respiratory symptoms.

\section{Food industry}

Artificial ETC is composed of cyt $\mathrm{c}$ and $\mathrm{SO}_{\mathrm{x}}$ formed by the layerby-layer technique using a polyelectrolyte. The multilayer technology of sulfite oxidase-cyt c multilayer electrode may act as an anode in a bio-fuel cell and may be exploited as a biosensor for the detection of sulfite in wine and other foodstuffs.

\section{Conclusion}

Sulfite oxidases catalyze the physiologically vital oxidation of sulfite to sulfate in animals, plants and bacteria. Its enzymatic activity 
can be affected by various factors: $\mathrm{pH}$, temperature and inhibitor. Each type of sulfite oxidase has a distinct optimum $\mathrm{pH}, \mathrm{pH}$ stability, an optimum temperature and temperature stability. The molecular weights of $\mathrm{SO}_{\mathrm{x}}$ purified from different sources were in the range, 27 to $113 \mathrm{kDa}$. The optimum $\mathrm{pH}$ of $\mathrm{SO}_{\mathrm{x}}$ purified from different sources was in neutral to alkaline range i.e. $\mathrm{pH} 7-11$. SOx isolated and purified from different sources had a wide range of optimum temperature 20$60^{\circ} \mathrm{C} \mathrm{K}$ for $\mathrm{SO}_{\mathrm{x}}$ was found in a wide range, $0.00092 \mathrm{mM}$ to $5.33 \mathrm{mM}$. $\mathrm{SO}_{\mathrm{x}}$ from various sources was inhibited by a number of compounds including metal ions and substrate analogues such as arsenite, EDTA, imidazole, Ethyl-3 (3-dimethylaminopropyl) carbodiimide hydrochloride, diethylpyro-carbonate, N-ethyl-5-phenylisoxazolium3'-sulfonate, 2,6-dichloroindophenol, cyanide, cyt c, ferricyanide, sodium tungstate, $\mathrm{NaCl}$, potassium nitrate, potassium phosphate and Tris- $\mathrm{HCl}$ buffer. Sulfite oxidase is used in reductive or oxidative sulfur metabolism, antioxidants, antimicrobials and bleaching agents, preservatives in medicine and food industry. The conventional method is used for highly purified sulfite oxidase involves ammonium sulfate fractionation, gel filtration or anion exchange chromatography.. The characteristics of sulfite oxidas are assayed by enzyme activity and concentration, specific activity (SA), purification factor (PF), molecular weight, homogeneity and isoelectric point (pI). Sulfite oxidase is considered a promising enzyme with wide applications in both conventional and new industries and new efficient, cost effective techniques for its recovery and purification should be developed.

\section{Acknowledgments}

None

\section{Conflicts of interest}

The author declares there are no conflicts of interest.

\section{References}

1. Giovanni D'Errico, Anna Di Salle, Francesco La Cara, et al. Identification and characterization of a novel bacterial sulfite oxidase with no heme binding domain from Deinococcus radiodurans. J Bacteriol. 188(2):694-701

2. Tan WH, Eichler FS, Hoda S, et al. Isolated sulfite oxidase deficiency: a case report with a novel mutation and review of the literature. Pediatrics. 2005;116(3):757-766.

3. Cohen HJ, Betcher-Lange S, Kessler DL, et al. Hepatic sulfite oxidase congruency in mitochondria of prosthetic groups and activity. $J$ Biol Chem. 1972;247(23):7759-7766.

4. Eilers T, Schwarz G, Brinkmann H, et al. Identification and biochemical characterization of Arabidopsis thaliana sulfite oxidase a new player in plant sulfur metabolism. J Biol Chem. 2001;276(50):46989-46994.

5. Ahmad A, Sarfraz A. Screening and partial immunochemical characterization of sulfite oxidase from plant source. Indian J Exp Biol. 2010;48:83-86.

6. Muffler K, Ulber R. Fed-batch cultivation of the marine bacterium Sulfitobacter pontiacus using immobilized substrate and purification of sulfite oxidase by application of membrane adsorber technology. Biotech Bioeng. 2008;99:870-875.

7. Di Salle A, D'Errico G, La Cara F, et al. A novel thermostable sulfite oxidase from Thermus thermophilus: characterization of the enzyme, gene cloning and expression in Escherichia coli. Extremophiles 2006;10(6):587-598.
8. Ganai BA, Masood A, Baig MA. Isolation, purification and partial characterization of sulfite oxidase from Malva sylvestris. Phytochem. 1997;45:879-880.

9. Jolivet P, Bergeron E, Meunier JC. Evidence for sulfite oxidase activity in spinach leaves. Phytochem. 1995;40:667-672.

10. Toghrol F, Southerland WM. Purification of sulfite oxidase from Thiobacillus novellus: Evidence for presence of heme and molybdenum. J Biol Chem. 1983;258(11):6762-6766.

11. Johnson JL, Rajagopalan, KV. Purification and properties of sulfite oxidase from human liver. J Clin Invest. 1976;58:543-550.

12. Kessler DL, Rajagopalan KV. Purification and properties of sulfite oxidase from chicken liver: Presence of molybdenum in sulfite oxidase from diverse sources. J biol Chem. 1972;247(20):6566-6573.

13. Cohen HJ, Fridovich I. Hepatic Sulfite Oxidase - The nature and function of the Heme prosthetic groups. J Biol Chem. 1971;246:2367-2373.

14. MacLeod RM, Farkas W, Fridovich I, et al. Purification and properties of hepatic sulfite oxidase. J Biol Chem. 1961;236:1841-1846.

15. Onoue Y. Sulfite oxidase from Merluccius productus. Biochim Biophys Acta. 1980;615:48-58.

16. Ganai BA, Masood A, Zargar M, et al. Kinetics of sulfite oxidase purified from Malva sylvestris. J Ind Pollut Contr. 2006;22:77-82.

17. Wilson HL, Wilkinson SR, Rajagopalan KV. The G473D mutation impairs dimerization and catalysis in human sulfite oxidase. Biochem. 2006;45:2149-2160

18. Southerland WM, Winge DR, Rajagopalan KV. The domains of rat liver sulfite oxidase. Proteolytic separation and characterization. J Biol Chem. 1978;253:8747-8752.

19. Dronov R, Kurth DG, Möhwald H, et al. Layer-by-layer arrangement by protein-protein interaction of sulfite oxidase and cytochrome c catalyzing oxidation of sulfite. J Am Chem Soc. 2008;130:1122-1123.

20. Negishi A, Muraoka T, Maeda T, et al. Growth inhibition by tungsten in the sulfur-oxidizing bacterium Acidithiobacillus thiooxidans. Biosci Biotechnol Biochem. 2005;69:2073-2080.

21. Shibuya A, Horie S. Studies on the composition of the mitochondrial sulfite oxidase system. J Biochem. 1980187:1773-1784.

22. Wilson HL, Rajagopalan KV. The role of tyrosine 343 in substrate binding and catalysis by human sulfite oxidase. J Biol Chem. 2004;279:1510515113.

23. Ritzmann M, Bosshard HR. Sulfite oxidase from chicken liver. Further characterization of the role of carboxyl groups in the reaction with cytochrome c. Eur J Biochem. 1988;172:377-381.

24. Bray RC. The Enzymes, Molybdenum iron-sulfur flavin hydroxylases and related enzymes. In: Boyer PD, editor. 1975;12:299-419.

25. Shibuya A, Horie S. Studies on the composition of the mitochondrial sulfite oxidase system. J Biochem. 1980;87:1773-1784.

26. Ito A, Kuwahara T, Mitsunari Y, et al. Distribution of hepatic sulfite oxidase among subcellular organelles and its intraorganelle localization. J Biochem. 1977;81:1531-1541.

27. Kuwahara T, Yoshimoto I, Ito A. Comparative immunochemical studies of sulfite oxidases of vertebrate livers. J Biochem. 1982;92:1925-1931.

28. George GN, Garrett RM, Graf T, et al. Interaction of arsenate with the molybdenum site of sulfite oxidase. J Am Chem Soc. 1998;120:45224523. 